Boise State University

ScholarWorks

Geosciences Faculty Publications and

Presentations

Department of Geosciences

$10-2015$

\title{
Landslides and Megathrust Splay Faults Captured by the Late Holocene Sediment Record of Eastern Prince William Sound, Alaska
}

\author{
Shaun P. Finn \\ Boise State University \\ Lee M. Liberty \\ Boise State University \\ Peter J. Haeussler \\ U.S. Geological Survey \\ Thomas L. Pratt \\ U.S. Geological Survey
}

Finn, Shaun, Liberty, Lee, Heussler, Peter, and Pratt, Thomas. Landslides and Megathrust Splay Faults Captured by the Late Holocene Sediment Record of Eastern Prince William Sound, Alaska. Bulletin of the Seismological Society of America, 105, pp. 2343-2353, 2015, @ Seismological Society of America. 


\section{Bulletin of the Seismological Society of America}

This copy is for distribution only by

the authors of the article and their institutions in accordance with the Open Access Policy of the Seismological Society of America.

For more information see the publications section of the SSA website at www.seismosoc.org

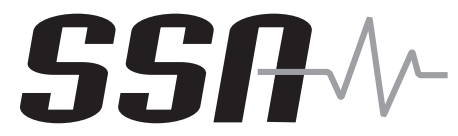

The Seismological Society of America 400 Evelyn Ave., Suite 201

Albany, CA 94706-1375

(510) 525-5474; FAX (510) 525-7204

www.seismosoc.org 


\title{
Landslides and Megathrust Splay Faults Captured by the Late Holocene Sediment Record of Eastern Prince William Sound, Alaska
}

\author{
by Shaun P. Finn, Lee M. Liberty, Peter J. Haeussler, and Thomas L. Pratt
}

\begin{abstract}
We present new marine seismic-reflection profiles and bathymetric maps to characterize Holocene depositional patterns, submarine landslides, and active faults beneath eastern and central Prince William Sound (PWS), Alaska, which is the eastern rupture patch of the $1964 M_{\mathrm{w}} 9.2$ earthquake. We show evidence that submarine landslides, many of which are likely earthquake triggered, repeatedly released along the southern margin of Orca Bay in eastern PWS. We document motion on reverse faults during the 1964 Great Alaska earthquake and estimate late Holocene slip rates for these growth faults, which splay from the subduction zone megathrust. Regional bathymetric lineations help define the faults that extend 40-70 km in length, some of which show slip rates as great as $3.75 \mathrm{~mm} / \mathrm{yr}$. We infer that faults mapped below eastern PWS connect to faults mapped beneath central PWS and possibly onto the Alaska mainland via an en echelon style of faulting. Moderate $\left(M_{\mathrm{w}}>4\right)$ upper-plate earthquakes since 1964 give rise to the possibility that these faults may rupture independently to potentially generate $M_{\mathrm{w}}$ 7-8 earthquakes, and that these earthquakes could damage local infrastructure from ground shaking. Submarine landslides, regardless of the source of initiation, could generate local tsunamis to produce large run-ups along nearby shorelines. In a more general sense, the PWS area shows that faults that splay from the underlying plate boundary present proximal, perhaps independent seismic sources within the accretionary prism, creating a broad zone of potential surface rupture that can extend inland $150 \mathrm{~km}$ or more from subduction zone trenches.
\end{abstract}

\section{Introduction}

The Prince William Sound (PWS) region of southern Alaska (Fig. 1) experiences large subduction-related earthquakes $\left(M_{\mathrm{w}}>8\right)$ on average every 300-900 years (e.g., Carver and Plafker, 2008). The $1964 M_{\mathrm{w}} 9.2$ earthquake, with an epicenter on mainland Alaska about $70 \mathrm{~km}$ west of the town of Valdez (Fig. 1), was the latest of these megathrust earthquakes and remains the second largest instrumentally recorded earthquake. Although large earthquakes along the Alaska-Aleutian megathrust typically result from the northward subduction of the Pacific plate beneath the North American plate, the PWS area includes the added subduction of the Yakutat terrane that appears to locally override the Pacific plate (e.g., Brocher et al., 1994; Eberhart-Phillips et al., 2006). During the 1964 earthquake, and likely during most Holocene megathrust earthquakes in the area, the largest coseismic surface ruptures were associated with splay faults that surface near the southwest limits of PWS (Plafker, 1969; Liberty et al., 2013). To date, there has been little direct evidence that these active splay faults extend northeast beneath PWS, closer to the 1964 earthquake epicenter and the population centers of Valdez and Cordova.
The subduction of the relatively buoyant Yakutat terrane above the Pacific plate and beneath the North American plate produces a shallow subduction angle compared with farther west where only Pacific plate rocks are being subducted (Brocher et al., 1994; Eberhart-Phillips et al., 2006; Fuis et al., 2008). Splay faults that extend from the subduction interface to the seafloor or land on the Alaska continental shelf accommodate the bulk of upper-plate coseismic motion for large earthquakes in the region, and these thrust faults strongly influence island formation in the PWS area (e.g., Plafker, 1969; Liberty et al., 2013; Haeussler et al., 2015). The only documented surface ruptures from the 1964 earthquake occurred on Montague Island in southwest PWS and on the adjacent Gulf of Alaska seafloor (Fig. 1; Plafker, 1969). These surface-rupturing faults accommodated much of the $21 \mathrm{~m}$ of slip caused by the earthquake, with upward of 5-12 m vertical uplift on multiple faults (Plafker, 1969; Liberty et al., 2013). Although Plafker (1969) documented no vertical displacement on individual faults on the islands of eastern PWS, upwards of $2 \mathrm{~m}$ of regional tectonic uplift may indicate coseismic slip on submarine faults in this area. 


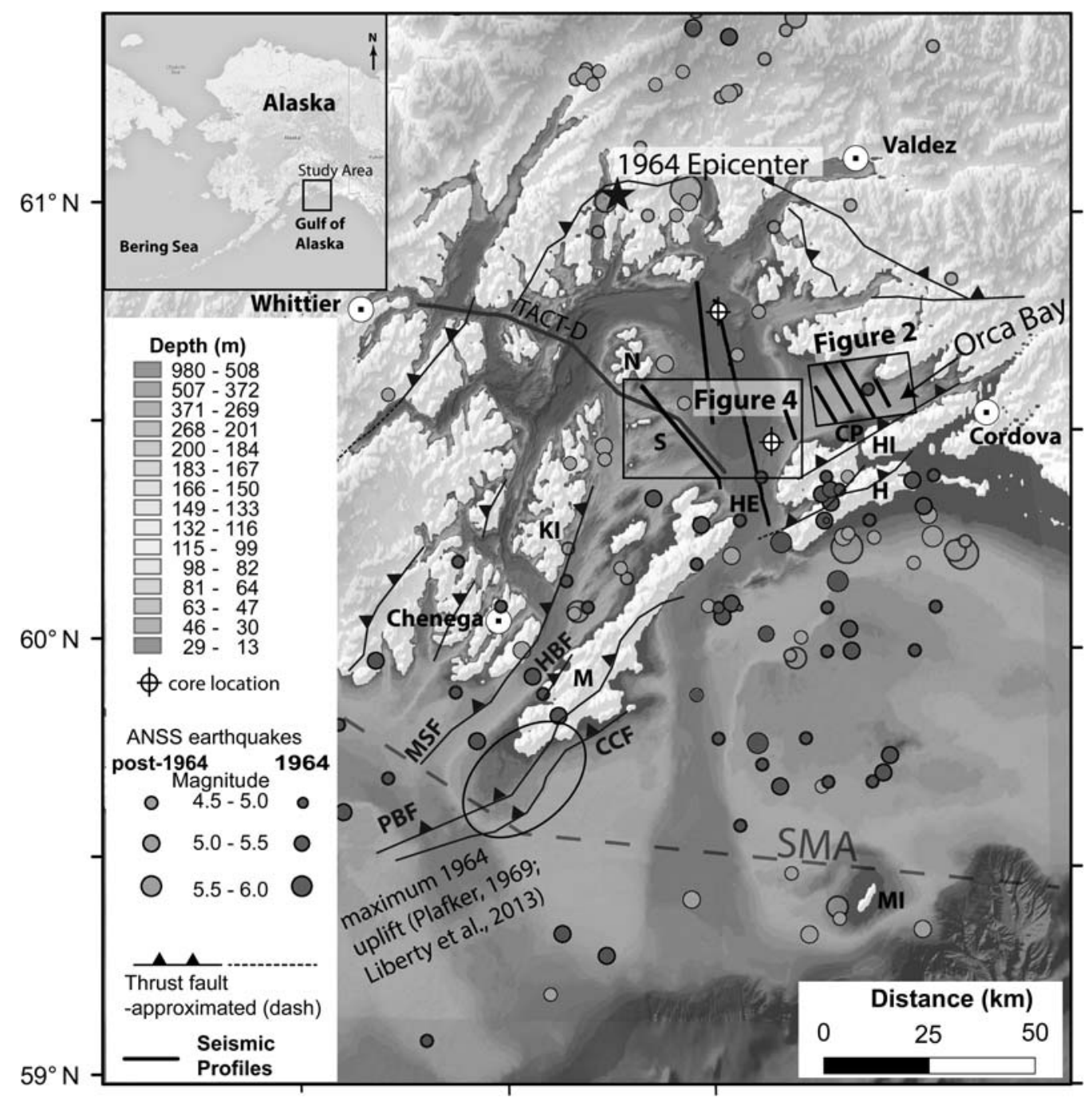

Figure 1. Prince William Sound (PWS) area map with seismic profiles (black lines) discussed in this study. Figure 2 (Orca Bay) and Figure 4 (central PWS) study areas are outlined in rectangles. Mapped thrust faults are shown as sawtooth lines (Wilson and Hults, 2012; Liberty et al., 2013; Haeussler et al., 2015). Faults that slipped during the 1964 Great Alaska earthquake include the Patton Bay fault (PBF), Hanning Bay fault (HBF), and Cape Cleare fault (CCF). The $1964 M_{\mathrm{w}} 9.2$ earthquake epicenter (star), aftershocks (dark circles), and post1964 (light circles) upper-plate earthquakes of $M_{\mathrm{w}}>4$ indicate interseismic slip. Islands include Montague (M), Hinchinbrook (H), Knight (KI), Hawkins (HI), and Naked and Smith (S). The communities of Valdez, Whittier, Cordova, and Chenega appear as open circles. Noted waterways include Hinchinbrook Entrance (HE) and the Canoe Passage (CP). The slope magnetic anomaly (SMA) defines the trailing and southwestern edge of the subducted Yakutat block (Griscom and Sauer, 1990).

In 2009 and 2011, we collected high-resolution marine seismic-reflection profiles to characterize Holocene depositional patterns and to identify active faults beneath PWS. Here, we show evidence for the rapid onset of late Holocene sediment deposition related to rising sea levels, glacial retreat, and an increased sediment supply from the Copper River just east of PWS. Coupled with multibeam seafloor images, we show evidence for repeated late Holocene submarine landslides that may have been earthquake triggered. We then present evidence that active faults cut the youngest marine deposits and that these faults have remained active throughout the late Holocene. Finally, we present a crustal-scale seismic profile that shows the identified faults splay from the megathrust interface. We show that PWS landslides and fault ruptures have repeatedly been active during the past few thousand years and that these hazards may initiate independently or in concert with a great megathrust earthquake.

\section{The 1964 Great Alaska Earthquake}

The $1964 M_{\mathrm{w}} 9.2$ Great Alaska earthquake caused 115 fatalities in Alaska and more than \$300 million (1964 dollars) in damage to Alaska infrastructure, despite the sparse population at the time (Haas, 1973). The epicenter was located in northern PWS and west of the town of Valdez, and approximately $150 \mathrm{~km}$ north of the location of greatest coseismic surface uplift (Fig. 1; Plafker, 1969; Liberty et al., 2013). Damage from ground shaking was widespread, and the associated tsunamis inundated coastline infrastructure as far away as northern California. Local tsunamis damaged the Alaska 
port communities of Whittier, Cordova, and Seward, and essentially destroyed the towns of Valdez and Chenega (Fig. 1).

The maximum coseismic uplift during the 1964 earthquake occurred near southwestern PWS above faults that roughly parallel the Montague Island shoreline (Fig. 1) (Plafker, 1969; Liberty et al., 2013). The Hanning Bay and Patton Bay faults had 5 and $10 \mathrm{~m}$ of differential vertical slip on Montague Island, respectively (Plafker, 1969), but the greatest vertical uplift was located beneath the shallow waters immediately west of Montague Island. Using bathymetric differencing techniques from pre- and postearthquake data, Malloy (1964) and Liberty et al. (2013) mapped these faults to the southwest beneath the Gulf of Alaska. High-resolution sparker seismic profiles suggest the associated growth faults have remained active throughout the deposition of the Quaternary sediments (Liberty et al., 2013). Plafker (1969) identified 1964 fault motion on only a portion of Montague Island but speculated these same faults extend beneath PWS to the Alaska mainland near Cordova. Upper-plate aftershocks as large as $M_{\mathrm{w}} 5$ related to the 1964 earthquake in the area from eastern Montague Island to Cordova support this supposition (Fig. 1).

\section{Tectonic Setting and Earthquake History}

The PWS region is located above the Alaska subduction zone plate boundary where oblique regional tectonic shortening is observed (Freymueller et al., 2008). Brittle failure in this north-directed compressional system causes slip on multiplethrust faults, which are referred to as megathrust splay faults that splay from the master decollement or megathrust.

Geodetic data show that the islands within PWS are moving at Pacific plate rates and currently accumulating strain that may release during the next large earthquake (Freymueller et al., 2008). This contrasts with motion on mainland Alaska, which is currently moving at the North American plate rate and direction (e.g., Zweck et al., 2002). Although the entire PWS region was uplifted in 1964, geodetic data show that central PWS has been gradually subsiding since the earthquake, consistent with a locked megathrust interface (Freymueller et al., 2008). The relatively moderate interseismic subsidence contrasts with the estimated millennial-scale exhumation rates of greater than $1 \mathrm{~mm} / \mathrm{yr}$ recorded with thermochronology methods for rocks in the hanging wall of the Patton Bay megathrust splay fault (Arkle et al., 2013; Ferguson et al., 2015; Haeussler et al., 2015). Hence, coseismic uplift rates have outpaced interseismic subsidence rates in the hanging wall of these splay faults for PWS throughout the Quaternary record. North of this region in PWS, the thermochronology data indicate that the interseismic subsidence has nearly matched coseismic uplift for more than $10 \mathrm{Ma}$, resulting in little elevation change (Haeussler et al., 2015).

Doser et al. (2008) characterized PWS seismicity and determined that thrust fault earthquakes are dominant in the upper crust above about $14 \mathrm{~km}$ depth. Post-1964 earthquake upper-plate seismicity forms clusters that are concentrated at several areas beneath PWS, including the Smith and Knight Island regions (Fig. 1; Doser and Brown, 2001; Fuis et al., 2008; Li et al., 2013). Although deformation and seismic moment release have been relatively low in the years following the 1964 earthquake (e.g., Doser et al., 2004), numerous $M_{\mathrm{w}}>4$ upper-plate earthquakes have been identified beneath and south of eastern PWS since 1964 (Fig. 1). These earthquakes likely originated along faults that splay from the megathrust at approximately $20 \mathrm{~km}$ depth (e.g., Brocher et al., 1994).

Past geophysical surveys shed light on the tectonic framework for PWS and the nearby Gulf of Alaska areas. Crustalscale seismic refraction and reflection data provide evidence for underthrusting or duplexing of the Pacific plate beneath the Yakutat terrane, and for splay faults emerging at depth from a regional decollement (Brocher et al., 1994; Fruehn et al., 1999; Fuis et al., 2008; Liberty et al., 2013; Haeussler et al., 2015). Modeling of magnetic data provides compelling evidence that the trailing edge of the Yakutat terrane, marked by the slope magnetic anomaly (SMA), lies between Montague and Middleton Islands (Fig. 1; Griscom and Sauer, 1990). Seismic tomography data show an increase in subduction angle near the southwestern extent of the Yakutat plate along the western margin of PWS (Eberhart-Phillips et al., 2006).

\section{Data Sources}

We interpret subsurface stratigraphy from our PWS sparker profiles and legacy seismic-reflection profiles from the Gulf of Alaska (e.g., von Huene et al., 1967; Molnia, 1977; Carlson and Molnia, 1978; Liberty et al., 2013). We also use shallow piston and gravity cores and seafloor sample data to obtain modern rates of deposition (e.g., Klein, 1983; Page et al., 1995; Jaeger et al., 1998; Evans et al., 2000; Jaeger and Nittrouer, 2006). Crustal-scale air gun seismic data were collected during the 1988 Trans-Alaska Crustal Transect (TACT) program. Brocher et al. (1994) interpreted refraction data from this survey that utilized PWS island-based seismometers. Fruehn et al. (1999), Liberty et al. (2013), and Haeussler et al. (2015) have published TACT reflection data that highlight plate boundary and splay fault geometries. We reprocessed the 7700-cubic-inch, 240-channel TACT-D segment of the reflection seismic profile within PWS for this study. We also acquired new high-resolution marine seismic-reflection data, which have a wavelength of about $1 \mathrm{~m}$, from the U.S. Geological Survey Research Vessel Alaskan Gyre during the 2009 and 2011 field seasons. These data have a sparker source set for 200-500 J and were recorded on both single-channel and 12-channel (3-m spaced) hydrophone streamer systems. Shot intervals of $0.8-1.2 \mathrm{~s}$ resulted in a spatial sampling of $1.5-3 \mathrm{~m}$. We used a standard marine seismic processing approach described by Yilmaz (2001) for both sparker and air gun data. Processing steps included velocity analysis, deconvolution, band-pass filtering, and poststack Kirchhoff migration. The reflection profiles were depth converted using the seis- 
(a)
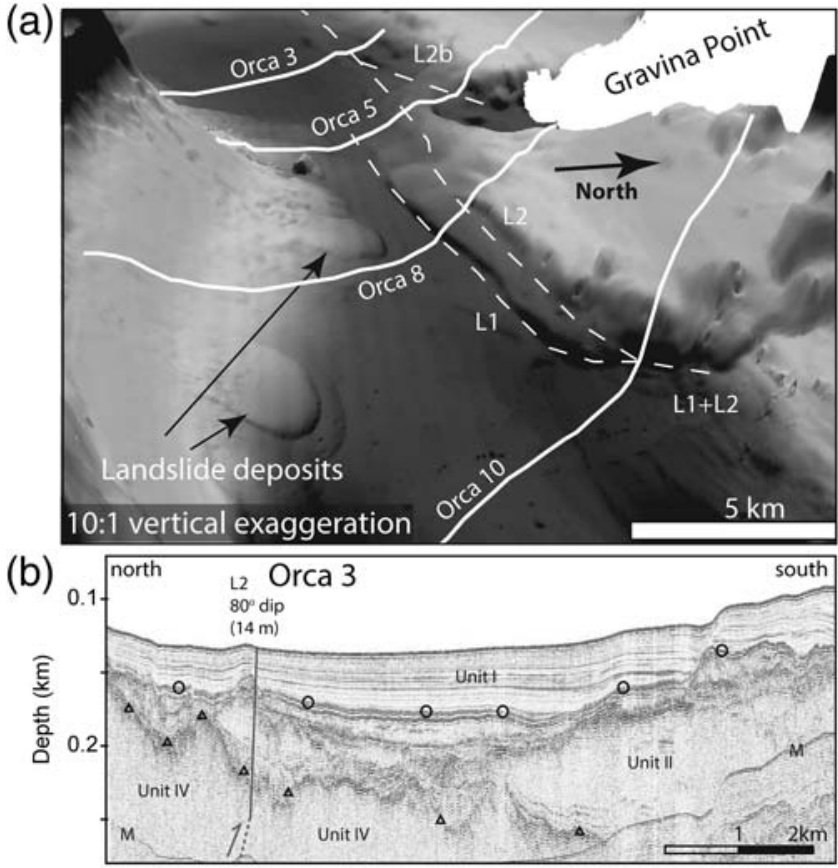

(c)

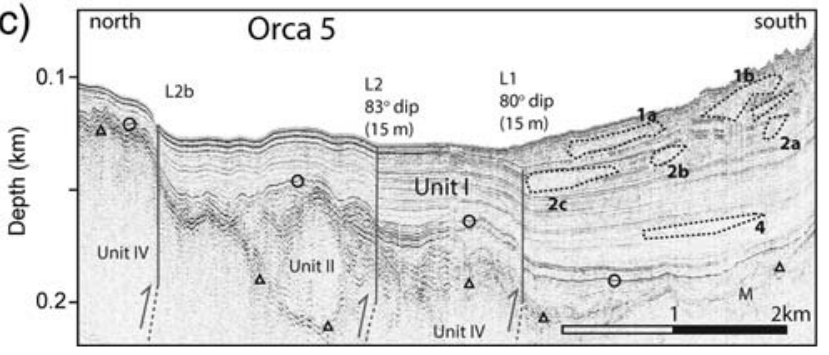

Figure 2. (a) West-looking bathymetric view of Orca Bay (National Oceanic and Atmospheric [NOAA] hydrographic database H11608, H11637, and H11499) showing seismic profile locations projected to the water bottom (solid lines), identified faults L1 and L2 (dashed lines), and two submarine landslides along the southern margin of Orca Bay. Light to dark shading represents shallow to deep water, (b) seismic profile Orca3, (c) seismic profile Orca5. (b,c) Fault dips are measured from truncated reflectors, the neoglacial unconformity (NGU) (unit I base) is identified with open circles, fault offsets across the NGU are labeled above each fault in parentheses, the top of Tertiary Orca Group rocks is identified with open triangles, and $\mathrm{M}$ is the water bottom multiple. Interpreted landslide deposits are shown as dashed areas. Vertical exaggeration is approximately 20:1.

mic refraction velocities from Brocher et al. (1994) and a water velocity of $1480 \mathrm{~m} / \mathrm{s}$. The short streamer lengths relative to imaging depths prevented effective velocity determinations from stacking velocities for either the air gun or the sparker data.

\section{PWS Seismic Stratigraphy}

The sparker and legacy air gun seismic data characterize the thickness of the youngest highly reflective depositional unit, which we interpret as late Holocene postglacial and fluvial deposits carried from the Copper River region south of Cordova (Fig. 1) and from other local river and tidewater glacial sources (Jaeger et al., 1998). The thickness of this youngest stratigraphic unit (unit I) is greater than 200 m near Hinchinbrook Entrance and in Orca Bay in PWS, where wellstratified sediments lie beneath a relatively smooth seafloor topography (Figs. 2 and 3; Molnia, 1977; Jaeger et al., 1998; Jaeger and Nittrouer, 2006). Seismic velocities for this late Holocene unit range from 1500 to $1600 \mathrm{~m} / \mathrm{s}$ (Brocher et al., 1994) and a prominent unconformity regionally defines the unit's base (Figs. 2 and 3; Liberty et al., 2013).

Piston and gravity core measurements, along with regional Holocene climate signals (e.g., Barclay et al., 2009), suggest that late Holocene rates of deposition vary considerably throughout PWS. However, many sources point to a middle Holocene unconformity (3-9 ka) that regionally lies beneath unit I strata (e.g., Jaeger et al., 1998; Barclay et al., 2009; Zander et al., 2013). The 16-m EW0408-98JC piston core near Hinchinbrook Entrance captured approximately 570 years of deposition, indicating a late Holocene depositional rate of $28 \mathrm{~mm} / \mathrm{yr}$ (J. Jaeger, oral comm., 2013). Extrapolating this rate of deposition down to the unit I base unconformity on the nearby profile CS4 (Fig. 4), we estimate the age of the underlying unconformity at $3500-4000 \mathrm{yr}$ B.P. A gravity core obtained near the northern limits of profile CS4 (Fig. 1) recorded a deposition rate of $5.7 \mathrm{~mm} / \mathrm{yr}$ for the past few hundred years (Page et al., 1995). Again, using this modern rate of deposition as a constant for the late Holocene record, the unit I basal unconformity would underlie $\sim 4500$ years of sediment. Using these sedimentation rates, we define the unit I unconformity base as consistent with the onset of rapid deposition following a 3.5-4.5 ka neoglacial pulse (e.g., Wiles et al., 2008; Barclay et al., 2009; Zander et al., 2013). We term this seismic boundary the neoglacial unconformity (NGU) and assume an onset of late Holocene deposition at $4 \mathrm{ka}$ for unit I beneath eastern PWS.

We define the unit II strata beneath unit I as early Holocene sediment that is typically less than a few hundred meters thick. Unit II has little internal reflectivity (Figs. 2, 3, and 4), which is consistent with coarse-grained postglacial deposits with interpreted seismic velocities that range from 1700 to $2200 \mathrm{~m} / \mathrm{s}$ (Brocher et al., 1994). Unit II is absent below many parts of PWS and the Gulf of Alaska (von Huene et al., 1967; Evans et al., 2000; Liberty, 2013; Liberty et al., 2013). We interpret unit II strata to represent the channeling and deposition of post last glacial maxima (LGM) sediments from PWS glaciers during a time when lower global sea levels (80-120 m below modern level) subaerially exposed much of PWS and the adjacent Gulf of Alaska (e.g., Peltier and Fairbanks, 2006). Although we can provide no age controls for this unit, we presume, based on strata positioning, that these sediments range in age from 6 to $12 \mathrm{ka}$.

A third, well-stratified seismic unit underlies Holocene units I and II in only some areas (e.g., profile CS5 in Fig. 4). Unit III locally shows kilometer-scale folding, reflector truncations from postdepositional faulting, and an overlying regional unconformity (Liberty et al., 2013). We interpret unit III to represent late Quaternary strata that were deposited prior to the LGM (older than $26 \mathrm{ka}$ ) and are likely equivalent 


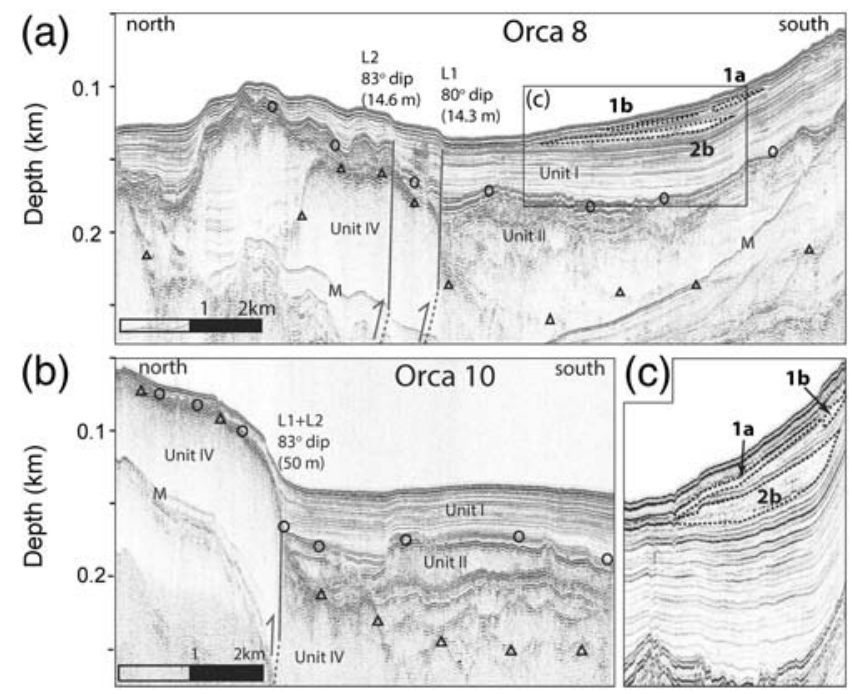

(d)
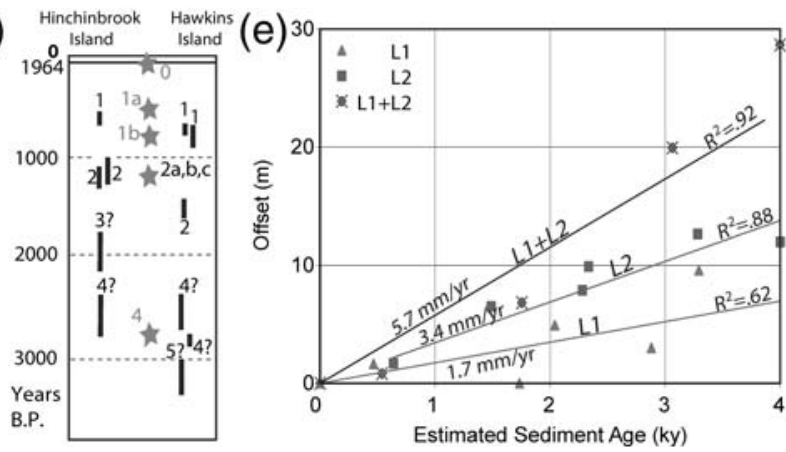

Figure 3. (a) Seismic profile Orca8, (b) seismic profile Orca10, (c) enlargement of Orca 8 from (a) to highlight landslide deposits (dashed areas). Labels are defined in Figure 2. (d) Carver and Plafker (2008) paleoseismic record (vertical bars) for Hawkins and Hinchinbrook Islands (Fig. 1) along with estimated submarine landslide ages (stars) observed on seismic profiles Orca 5 and 8, (e) calculated late Holocene slip rate for faults L1 and L2 for profiles Orca 8 and 10. Error estimate R2 is based on a least-squares fit to the measured offsets (assuming a constant rate of deposition for unit I). Vertical exaggeration is approximately 20:1 for (a) and (b).

to the late Pliocene/early Pleistocene Yakataga formation of Taliaferro (1932) that crop out on Middleton Island to the south of the study area (e.g., Lagoe et al., 1993; Fig. 1). From our PWS seismic profiles, we identify unit III only near Hinchinbrook Entrance (Fig. 4). These strata are also identified beneath parts of the Gulf of Alaska near Montague and Middleton Islands (Carlson and Molnia, 1978; Evans et al., 2000; Liberty et al., 2013).

We define the basal seismic unit IV as the Tertiary Orca Group of Moffit (1954), a unit that is exposed throughout much of the land around PWS (e.g., Wilson and Hults, 2012). We infer that these Tertiary rocks form the ocean-bottom surface where rugged seafloor topography prevails, and because of their hardness no sparker seismic signal penetration is obtained (e.g., Carlson and Molnia, 1978; Evans et al., 2000; Liberty et al., 2013). Brocher et al. (1994) measured seismic velocities that range from 3000 to $4600 \mathrm{~m} / \mathrm{s}$ within this unit, consistent with lithified sedimentary rocks.
Although we utilize average deposition rates from cores (e.g., Klein, 1983; Page et al., 1995), modern sediment deposition rates have varied both spatially and temporally throughout the Holocene in response to varying sediment sources and to climate, sea level changes, and tectonic forces (e.g., Jaeger et al., 1998). One example of this changing rate and source of deposition occurs in the Orca Bay region. Here, the bulk of the modern sediment has traveled through the Canoe Passage that separates Hinchinbrook and Hawkins Islands (Fig. 1). This modern waterway shallows in places to less than $2 \mathrm{~m}$ depth, and the passage was largely dry during early to middle Holocene times when sea level was more than a few meters below modern levels (e.g., Peltier and Fairbanks, 2006). Coseismic uplift during large earthquakes ( $\sim 1 \mathrm{~m}$ in 1964) may have further restricted flow through this passage.

\section{Submarine Landslide Deposits}

Multibeam bathymetry data from Orca Bay show modern submarine landslides along this modern delta that forms the northern slopes of Hinchinbrook Island and Hawkins Island (Fig. 2). With measured submarine slope angles along the southern margin of Orca Bay of less than $5^{\circ}$, these landslides are similar to other marine slope failure angles in the region (e.g., Haeussler et al., 2014).

Below the seafloor, we identify older landslide deposits within unit I that appear as seismically transparent zones within the late Holocene strata (dashed areas in Figs. 2c and $3 a, c)$. We interpret these seismically transparent zones as slumped or collapsed marine deposits, and these submarine landslide deposits extend as much as $5 \mathrm{~km}$ downslope north of Hinchinbrook Island. Based on stratigraphic positioning, a constant sedimentation rate, and a basal unconformity age of $4 \mathrm{ky}$, we approximate submarine landslide deposit ages at 570 (landslide 1a), 800 (landslide 1b), 1140 (landslides 2a-c), and 2800 (landslide 4) yr B.P. (Figs. 2 and 3). Although age estimates are poorly constrained and there is no direct evidence to suggest that these landslides are earthquake induced, landslides that activate every few hundred years are consistent with earthquake recurrence intervals (e.g., Carver and Plafker, 2008). For example, the estimated $\sim 570$ - to 800-year-old submarine landslides that we mapped may be related to the penultimate earthquake $\sim 800$ yr B.P. (Carver and Plafker, 2008; Fig. 3). Regardless of the mechanism for slide initiation, submarine landslides can cause localized tsunamis that can result in damage to coastal infrastructure.

\section{Orca Bay Active Faults}

To identify and characterize active faults in the Orca Bay region, we use seismic data, multibeam bathymetry, published piston and gravity core measurements, and geologic mapping from adjacent islands (e.g., Wilson and Hults, 2012). We include four 10- to 20-km long, north-south seismic profiles that 
(a)

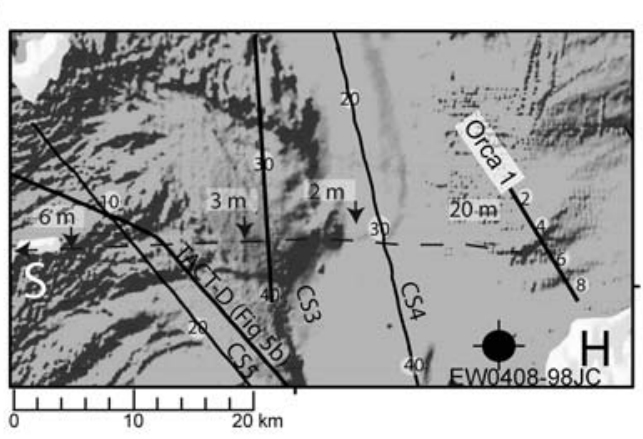

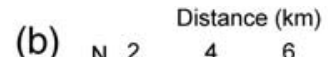
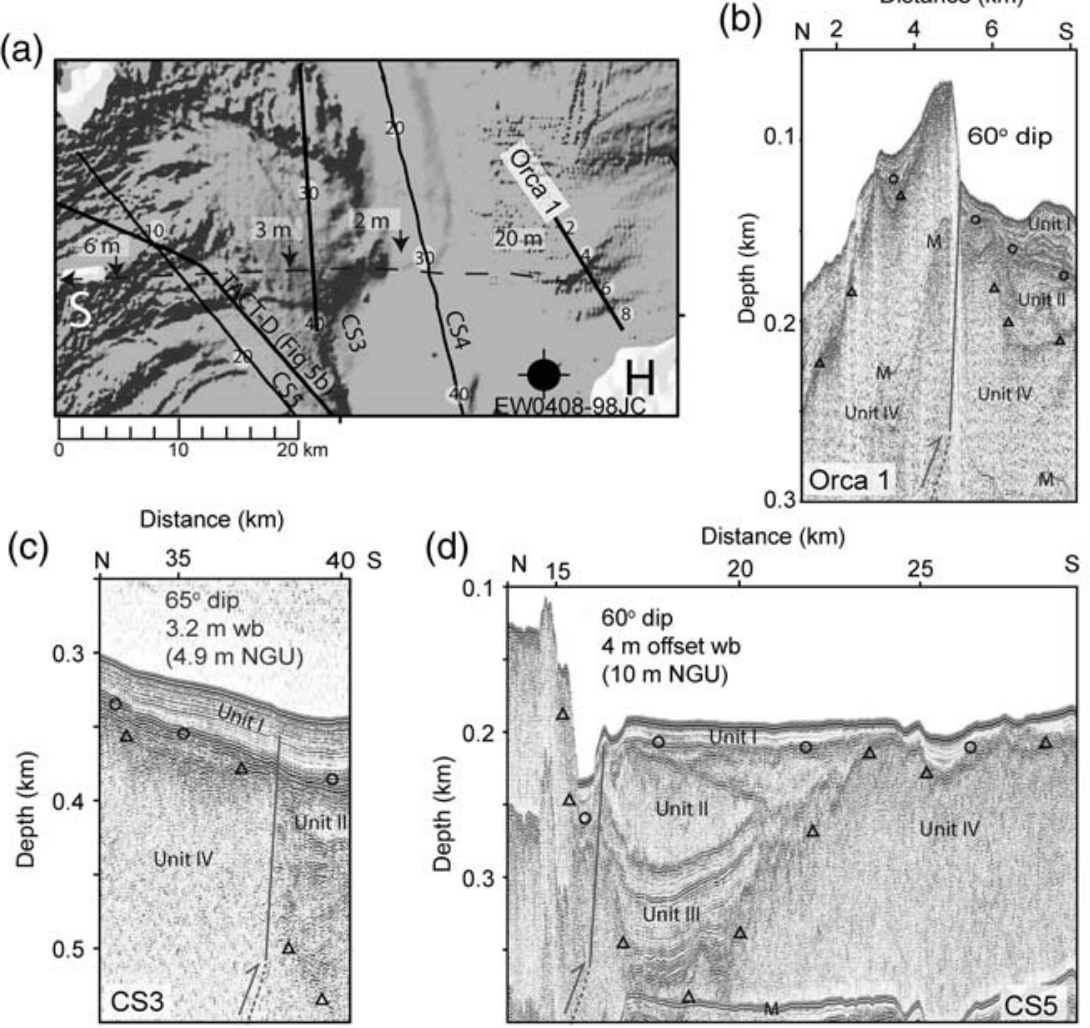

(d) Distance $(\mathrm{km})$

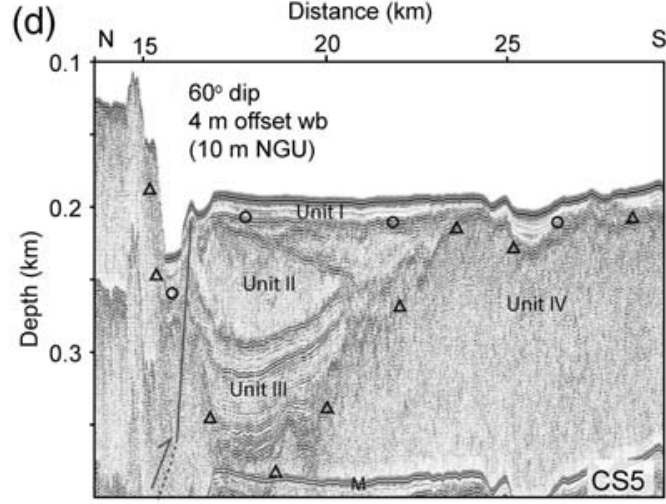

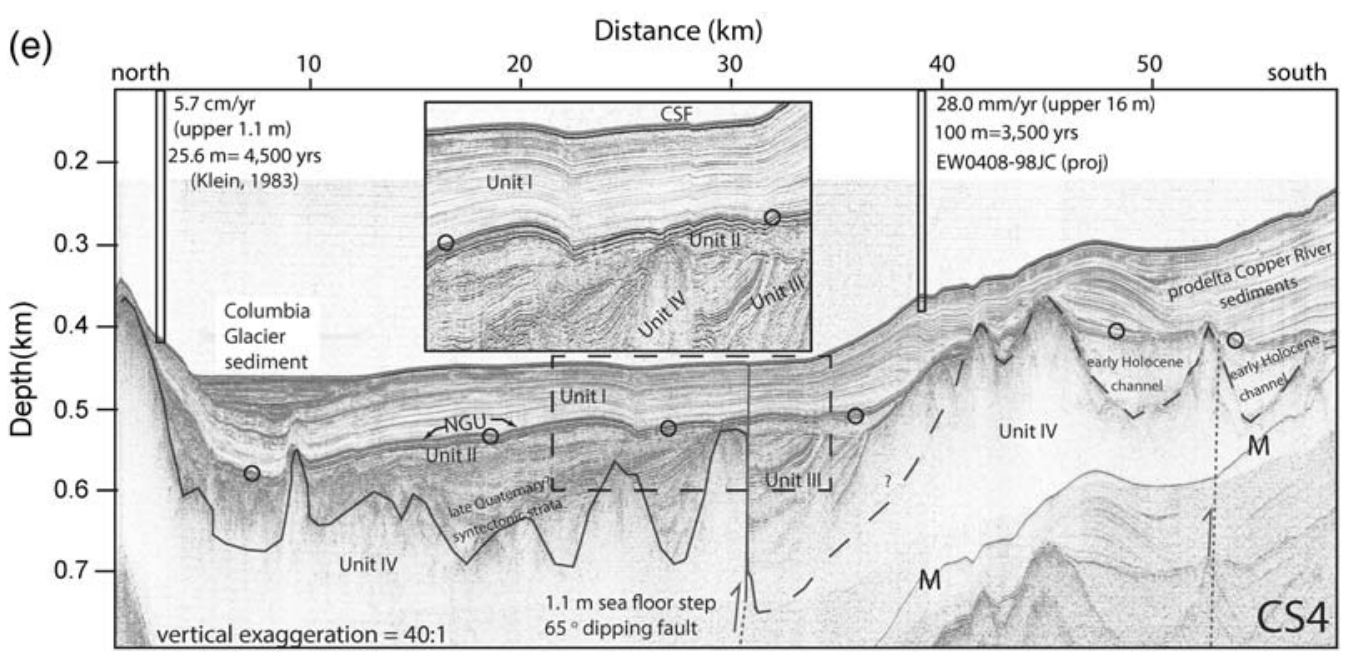

Figure 4. (a) Bathymetric derivative map for central PWS derived from seafloor slope difference measurements. Arrows and dashed line point to a water bottom scarp related to the Central Sound fault (CSF), with the associated number showing the amount of seafloor offset related to the fault. Location of 16-m piston core EW0408-98JC is noted and is the location of the Smith Islands (S). Seismic profiles are noted as black lines (b) seismic profile Orca 1, (c) seismic profile CS3, (d) seismic profile CS5, (e) seismic profile CS4 and inset showing enlargement of area in dashed rectangle. Sediment deposition rates are extrapolated from the $1.1 \mathrm{~m}$ gravity core (Klein, 1983) and the 16-m EW0408-98JC piston core (J. M. Jaeger, oral comm., 2013). Vertical exaggeration is approximately 20:1 for (b)-(d).

image several hundred meters beneath the seafloor (Fig. 2). The multibeam bathymetry shows seafloor lineations $>60 \mathrm{~km}$ long and clear evidence for slumping or modern submarine landslide deposits.

We identify two east-west water-bottom lineations that extend beneath Orca Bay to the Hinchinbrook Entrance area of PWS, here labeled as L1 and L2 (Fig. 2). These lineations record seafloor offsets that range from 10 to $50 \mathrm{~m}$, project to
Tertiary bedrock lineations east of Orca Bay (Condon and Cass, 1958), and are subparallel to faults mapped on land to the east (e.g., Wilson and Hults, 2012). Based on offset reflectors and abrupt changes in stratal dip along the four seismic profiles, we interpret these lineaments as marking subparallel faults and folding above the faults (Figs. 2 and 3). From reflector truncations, we measure $\sim 80^{\circ} \mathrm{N}$ dipping reverse faults that offset late Holocene strata. All four seismic 
profiles show increasing reflector offsets with depth that indicate late Holocene growth faulting.

We calculate late Holocene slip rates for faults L1 and L2 assuming that the NGU reflector initiated as a horizontal surface (Figs. 2 and 3). We identify matching reflectors within unit I on the hanging wall and footwall sides of each identified fault. Assuming a constant sedimentation rate to the NGU boundary but allowing for sedimentation rates that vary for each profile, we calculate slip averages. From seismic profile Orca 8 , we observe a 6.5 -m seafloor scarp (from multibeam data) and about a 14-m NGU offset for lineament L1. Assuming a 4-ky NGU boundary, we calculate a late Holocene average slip rate of $3.5 \mathrm{~mm} / \mathrm{yr}$. For lineament L2, we observe a 7.8-m seafloor scarp and about a 15-m NGU offset, or a similar late Holocene average slip rate of $3.75 \mathrm{~mm} / \mathrm{yr}$. On seismic profile Orca 10, lineaments L1 and L2 form a single fault with a seafloor offset of more than $50 \mathrm{~m}$ and an approximately $75 \mathrm{~m}$ offset of the NGU reflector. This offset across the NGU reflector is consistent with combined L1 and L2 slip measured on adjacent profiles. These large offsets suggest that the 1964 earthquake did not produce all of the seafloor topography. Increasing offset with depth across L1/L2 lineaments on these profiles suggests late Holocene growth faulting on these reverse faults.

Carver and Plafker (2008) suggested an average recurrence interval of 589 years for large megathrust earthquakes near PWS. Plafker (1969) estimated that between 0.5 and $2 \mathrm{~m}$ of regional vertical uplift occurred within Orca Bay during the 1964 earthquake, but his study did not identify any coseismic ruptures beneath Orca Bay in 1964. The measured late Holocene offsets across the L1/L2 lineaments are clearly larger than an average $2 \mathrm{~m}$ slip per large earthquake. This discrepancy suggests that: (1) the 1964 earthquake had less tectonic uplift in eastern PWS than previous large earthquakes, (2) the NGU in this area is older than 4000 years estimated from modern rates of deposition, or (3) the time gap between units I and II deposition spans many thousands of years (e.g., Zander et al., 2013) and the NGU offset records a longer earthquake record. Previous studies suggested that the 1964 earthquake did not extend as far east as previous large earthquakes (e.g., Carver and Plafker, 2008; McCalpin and Carver, 2009; Shennan et al., 2014), perhaps accounting for larger slip estimates near western PWS for the last few pre-1964 earthquakes (Liberty et al., 2013).

$M_{\mathrm{w}}>4$ earthquakes (both aftershocks and others since 1964) located below the Orca Bay region (Fig. 1) may lie along the L1 and L2 faults (at depth) and suggest that these faults may rupture independently of the large megathrust earthquakes. Although it is not clear whether pre-1964 $M_{\mathrm{w}}>7$ earthquakes initiated in the upper plate, Doser (2006) relocated older earthquakes to lie beneath eastern PWS in the vicinity of Orca Bay. Finally, using empirical relationships for subsurface rupture lengths from Wells and Coppersmith (1994), slip along the $\sim 60 \mathrm{~km}$ length of the L1/L2 faults beneath Orca Bay could independently support an $M_{\mathrm{w}} 7$ earthquake. If these faults extend west beneath the central PWS re- gion or east into mainland Alaska, larger earthquakes are possible from this fault system.

\section{Central PWS Active Faults}

We present four new sparker seismic profiles and the TACT-D seismic-reflection profile that image strata and structure beneath the central PWS waterway between Orca Bay and Knight Island. This main shipping channel extends from Hinchinbrook Entrance to the port communities of Valdez and Whittier (Fig. 1). Our sparker seismic profiles reveal layered deposition, fluvial channeling, and in places bedrock forming the seafloor. When we interpret the seismic data in conjunction with seafloor bathymetry, we identify and characterize the active faults that lie beneath central PWS and that splay from the $\sim 20$-km-deep megathrust boundary at the top of the subducting plate (Fig. 5).

Extending from Orca Bay to central PWS, sparker profile Orca 1 reveals a $50 \mathrm{~m}$ bedrock (unit IV) high juxtaposed against Holocene strata (units I and II; Fig. 4). Although we cannot state with certainty that this bedrock knob is fault controlled, the southward thinning of unit I strata onto this bedrock surface is consistent with growth faulting. Along strike of the Orca 1 profile and at position $31 \mathrm{~km}$ on seismic profile CS4 (inset in Fig. 4e), we identify a 1.1-m vertical step of the seafloor (from detailed bathymetric measurements) and about a 3-m vertical step across the NGU that separates units I and II (Fig. 4). We also identify a 10-m offset of the reflector at the base of unit II, and more than 50-m offset separates the truncated reflectors of unit III from the unit IV Orca Group bedrock. Based on truncated reflectors, we interpret an $\sim 65^{\circ} \mathrm{N}$ dipping active thrust fault. The increase in offset with depth suggests that the fault we term the Central Sound fault (CSF) has remained active throughout late Quaternary time. Given the extremely rapid late Holocene deposition rates, we presume that most of the 1.1-m seafloor offset occurred during the 1964 earthquake. If the base of unit I represents the 4-ky NGU boundary and the base of unit II represents the onset of post LGM deposition at $12 \mathrm{ky}$, our measured offsets suggest a Holocene slip rate of approximately $0.75 \mathrm{~mm} / \mathrm{yr}$. Thus, slip from the 1964 earthquake represents more than the average vertical motion per earthquake on this fault, assuming five post-NGU earthquakes (Carver and Plafker, 2008). Alternatives to this interpretation are that the CSF was not active during all of the post-NGU earthquakes or that depositional rates have changed over the past few thousand years. This presumed higher than average slip from 1964 on the CSF is in contrast to the lower than average 1964 slip estimates for the Orca Bay faults. However, our observations suggest measurably different fault slip between earthquakes. Placed in a larger context though, the late Holocene motion on the CSF and Orca Bay fault is nearly an order of magnitude less than slip on the Patton Bay and Cape Cleare faults near the southern margin of Montague Island (Fig. 1; Liberty et al., 2013). 


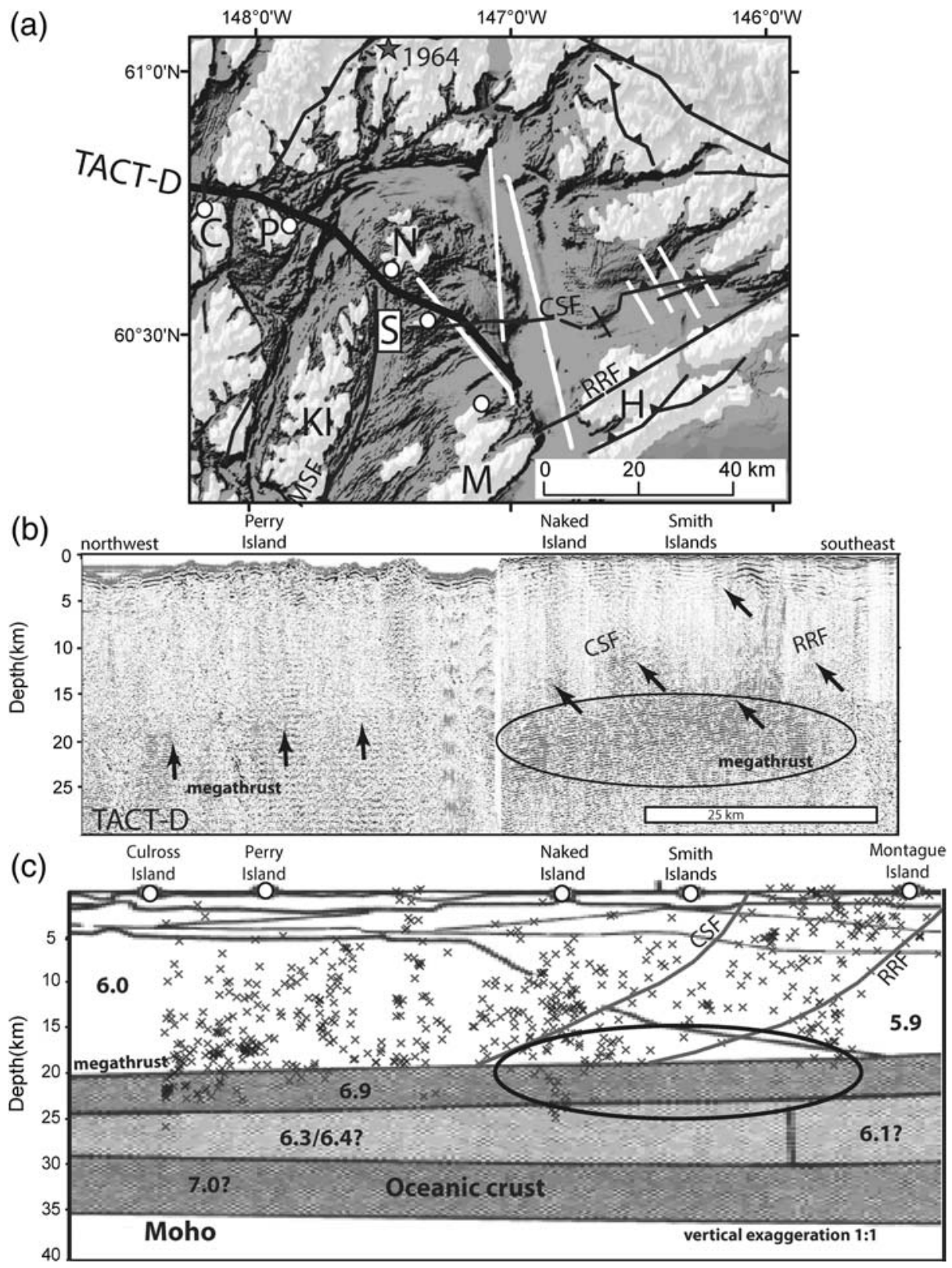

Figure 5. (a) Updated fault map for the eastern PWS area based on seismic and bathymetric data. Hinchinbrook Island (H), Montague Island (M), Smith Islands (S), Knight Island (KI), Perry Island (P), Culross Island (C), CSF, and Rude River fault (RRF). Montague Strait fault (MSF) is from Haeussler et al. (2015). (b) Trans-Alaska Crustal Transect (TACT)-D seismic profile showing strong midcrustal reflectivity related to Yakutat and Pacific plate reflectivity to the south of Naked Island. Arrows point to reflections from splay faults and plate boundary, and the ellipse outlines the area of high reflectivity associated with megathrust duplexing. (c) TACT refraction model (revised from Brocher et al., 1994) with earthquake hypocenters of $M_{\mathrm{w}}>2$ (from Doser et al., 2008) and interpreted faults that splay from the megathrust. The ellipse represents our interpreted zone of duplexing. Open circles in (a) and (c) represent island-based seismic stations used for refraction models (Brocher et al., 1994).

We identify the CSF on additional sparker seismic profiles and as a seafloor scarp that bisects the Smith Islands beneath central PWS (Fig. 4). On sparker seismic profile CS3, the CSF offsets the seafloor by $3.2 \mathrm{~m}$, the NGU by about $5 \mathrm{~m}$, and the bedrock by $\sim 130 \mathrm{~m}$. Profile CS5 shows water bottom and NGU offsets of 4 and $10 \mathrm{~m}$, respectively, and the seafloor offset near the Smith Islands records an offset of nearly $6 \mathrm{~m}$. Because Plafker (1969) recorded only $\sim 1.5 \mathrm{~m}$ vertical uplift during the
1964 earthquake on nearby islands, we presume that the seafloor uplift along these profiles does not represent uplift from only the 1964 earthquake. The 5-10 m offset across the NGU near the Smith Islands does suggest a larger average fault displacement per earthquake than on the CS4 profile to the east. This increase in uplift to the west is consistent with exhumation patterns recorded from thermochronology data that average over thousands of earthquake cycles (Arkle et al., 2013; 
Ferguson et al., 2015; Haeussler et al., 2015). To the west of the Smith Islands, there is no evidence from seismic profiling or seafloor bathymetry for along-strike uplift (Liberty, 2013). The CSF westward termination likely is related to a change in stress direction that is manifested in the northeast-striking faults that dominate the Knight Island and southern Montague Island region (Plafker, 1969; Wilson and Hults, 2012; Liberty et al., 2013; Haeussler et al., 2015).

In the footwall of the CSF, pre-NGU strata dip to the north by $5^{\circ}$ or more (Fig. 4e), suggesting that another late Quaternary fault is present near Hinchinbrook Entrance. We do not identify any unit I offsets to the south of the CSF on profile CS4, suggesting that we either missed this additional fault with profile CS4 or that high rates of deposition in southern PWS have obscured the fault motion. We relate this inferred southern fault to the Rude River fault (RRF) system, an $\mathrm{N} 45^{\circ} \mathrm{E}$ striking reverse fault mapped on Hinchinbrook Island and Hawkins Island (Fig. 1). The RRF system did not rupture during the 1964 earthquake, but it does deform late Pleistocene glacial deposits on Hinchinbrook and Hawkins Islands (Carver and McCalpin, 1996, p. 384). Similar to active faults to the southwest of Montague Island, this fault may not rupture with each large megathrust earthquake (Liberty et al., 2013).

\section{TACT Seismic Results}

The TACT-D seismic profile extends from near the port town of Whittier to Hinchinbrook Entrance (Fig. 1). Brocher et al. (1994) produced a velocity profile that revealed a large seismic velocity boundary at $15-20 \mathrm{~km}$ depth along this transect and identified this refractor to represent the top of the subducting plate or megathrust decollement, which separates the North American plate from the underlying Yakutat terrane and Pacific plate oceanic crust. Our interpretation of the TACT-D seismic-reflection profile is that it reveals a highly reflective zone at $15-20 \mathrm{~km}$ depth in the region between Naked Island and Hinchinbrook Entrance that is consistent with crustal duplexing (Fig. 5; Liberty et al., 2013). We interpret a series of nearly flat-lying reflectors (an average northward dip of $1^{\circ}-3^{\circ}$ ) at $\sim 20 \mathrm{~km}$ depth to represent the low-angle subduction decollement surface. The overlying reflectors dip gently to the north, and the reflector dips increase at shallow depths. We interpret these north-dipping reflectors to be thrust faults that splay from the megathrust. One splay fault surfaces immediately south of the Smith Islands at the seafloor lineation that represents the CSF, suggesting that the CSF is a megathrust splay fault. A second fault splays from the megathrust to the south of the CSF and projects to the surface south of the TACT-D profile. This latter splay fault is consistent with the positioning of the RRF system near Hinchinbrook Entrance and is likely responsible for the tilted reflectors in the footwall portion of the CSF (shown on CS4) and the shallow bedrock depth near Hinchinbrook Entrance.

The portion of the TACT-D profile to the north of Naked Island shows little evidence for upper-crustal reflectors be- low the Holocene sedimentary basins and seafloor bedrock exposures. It is unclear why the megathrust along this northern portion of the profile is poorly imaged, but we speculate that the smaller lower-plate velocity contrast documented by Brocher et al. (1994) points to a lack of duplexing below this part of northern PWS (Fig. 5). In addition, the lack of upperplate reflectors is consistent with few mapped thrust faults in this part of PWS and slow rates of long-term exhumation compared with other portions of PWS (Arkle et al., 2013; Haeussler et al., 2015).

\section{Discussion and Conclusions}

Much of eastern and central PWS has had very high rates of late Holocene sedimentation, and we identify active reverse faults that offset these young sediments. The CSF extends westward from the Smith Islands and east to Orca Bay (Fig. 4) and lineaments related to active faults define the northern margin of the deepest basin in Orca Bay. East of Orca Bay, lineaments and reverse faults are mapped on land (Condon, 1965; Plafker, 1969; Bol and Roeske, 1993; Wilson and Hults, 2012), and these lineations are possible onland continuations of the Orca Bay faults. We do not see a clear link between seafloor traces of the CSF and Orca Bay faults, and they may represent individual faults of an en echelon fault system. An en echelon pattern of faulting is consistent with 1964 slip recorded onshore and offshore Montague Island (Plafker, 1969; Liberty et al., 2013). If this Orca Bay-CSF system continuously extends the $70 \mathrm{~km}$ from the Smith Islands to Gravina Point east of Orca Bay, empirical data from other fault systems suggest the faults beneath eastern PWS could independently support an $M_{\mathrm{w}} 8$ earthquake (e.g., Wells and Coppersmith, 1994). However, the total vertical slip of a few meters along the NGU horizon within eastern and central PWS is small compared with offsets recorded southwest of Montague Island (Liberty et al., 2013), suggesting that the former area has likely not been the central focus of $M_{\mathrm{w}} 9$ late Holocene earthquake surface ruptures.

Faults and lineations related to the RRF that surfaces on Hinchinbrook Island indicate a thrust component (Carver and McCalpin, 1996) and may extend beneath Hinchinbrook Entrance to Montague Island to form a $>30-\mathrm{km}$-long fault system (Fig. 5). Although these faults show no measured displacement from the 1964 earthquake, this fault system has likely been active during previous Holocene earthquakes and we suggest it should be regarded as high hazard.

Beneath and around PWS, mapped faults follow the contours of the continental coastline (e.g., Wilson and Hults, 2012). In addition, midcrustal seismic velocity boundaries from tomographic data follow this same trend (EberhartPhillips et al., 2006). This trend differs from the subducted plate geometry along the bulk of the Aleutian trench. The changes in fault orientation and plate boundary conditions likely reflect a change in stress field associated with the varying geometry of the North America, Pacific, and Yakutat plates across the PWS region. The transition from north- 
east-striking faults beneath western PWS to east-striking faults beneath eastern PWS does not reflect differing generations of active faults but corupturing faults related to the same subduction zone processes.

The data and interpretations presented here add to the growing body of evidence that splay faults emanating from megathrust systems represent substantial seismic hazards and can cause surface ruptures more than $150 \mathrm{~km}$ landward of the toe of an accretionary prism. In the case of PWS, these faults splay from the nearly horizontal megathrust in an area where crustal duplexing is present. Although the focus of uplift has remained near western PWS for the past few millennia (Haeussler et al., 2015), these splay faults still pose substantial hazards to the proximal cities and towns throughout the region. What remains unclear is whether these large splay faults can rupture independently of the megathrust, making them significant seismic hazards at times other than during the great earthquakes.

In summary, we observe a set of previously unmapped landslides and en echelon active thrust faults beneath the eastern and central PWS region, an area that records large changes in spatial and temporal sediment depositional rates. These faults splay from a regional decollement that accommodates northward subduction of the Yakutat terrane and Pacific plates beneath the North American plate. These newly identified splay faults rupture during most megathrust earthquakes, and may be capable of generating up to $M_{\mathrm{w}} 8$ earthquakes at other times. We also find evidence of repeated submarine landslide activity in PWS that could have been earthquake induced. Faults and landslides suggest a high seismic and tsunami hazard to local communities and infrastructure of eastern PWS.

\section{Data and Resources}

The sparker seismic-reflection data presented in this article were archived with the University of Texas Institute for Geophysics data center (http://www.ig.utexas.edu/sdc/, last accessed August 2015). The Trans-Alaska Crustal Transect (TACT) multichannel seismic data were obtained from the U.S. Geological Survey and are available from Incorporated Research Institutions for Seismology (IRIS) (www.iris.edu, last accessed August 2014) as an assembled data set. The TACT data were obtained in 2011. Multibeam seafloor measurements were obtained from National Oceanic and Atmospheric (NOAA) National Geophysical Data Center (http:// maps.ngdc.noaa.gov/viewers/bathymetry/, last accessed August 2014). All earthquake data were obtained from the Advanced National Seismic System (ANSS) Comprehensive Catalog (ComCat) online database (http://earthquake.usgs. gov/earthquakes/search/, last accessed August 2014).

\section{Acknowledgments}

We would like to thank R/V Alaskan Gyre Captain Greg Snedgen for his assistance in making the seismic acquisition cruise a success. We are grateful for the anonymous reviewers' comments and the comments of
Associate Editor Brian Sherrod that improved the content of the article. ProMAX seismic processing software was provided by Landmark Graphics Corporation Strategic University Alliance Grant Agreement Number 2013-UGP-009000. This work was funded by the U.S. Geological Survey Earthquake Hazards Program Awards G09AP20143 and G11AP20143. Any use of trade, product, or firm names is for descriptive purposes only and does not imply endorsement by the U.S. Government.

\section{References}

Arkle, J. C., P. A. Armstrong, P. J. Haeussler, M. G. Prior, S. Hartman, K. L. Sendziak, and J. A. Brush (2013). Focused exhumation in the syntaxis of the western Chugach Mountains and Prince William Sound, Alaska, Bull. Geol. Soc. Am. 125, nos. 5/6, 776-793.

Barclay, D. J., G. C. Wiles, and P. E. Calkin (2009). Holocene glacier fluctuations in Alaska, Quaternary Sci. Rev. 28, 2034-2048, doi: 10.1016/ j.quascirev.2009.01.016.

Bol, A. J., and S. M. Roeske (1993). Strike-slip faulting and block rotation along the contact fault system, eastern Prince William Sound, Alaska, Tectonics 12, no. 1, 49-62.

Brocher, T. M., G. S. Fuis, M. A. Fisher, G. Plafker, M. J. Moses, J. J. Taber, and N. I. Christensen (1994). Mapping the megathrust beneath the northern Gulf of Alaska using wide-angle seismic data, J. Geophys. Res. 99, 11663-11686.

Carlson, P. R., and B. F. Molnia (1978). Minisparker profiles and sedimentologic data from R/V Acona cruise (April 1976) in the Gulf of Alaska and Prince William Sound, U.S. Department Interior Geol. Surv. Open-File Rept. 78-381, 1-33.

Carver, G., and G. Plafker (2008). Paloseismicity and neotectonics of the Aleutian subduction zone-An overview, in Active Tectonics and Seismic Potential of Alaska, J. Freymueller, P. Haeussler, R. Wesson, and G. Ekstrom (Editors), American Geophysical Monograph, 179, 43-63.

Carver, G. A., and J. P. McCalpin (1996). Paleoseismology of compressional tectonic environments, Int. Geophys. 62, 315-419.

Condon, W. H. (1965). Map of eastern Prince William Sound area, Alaska, showing fracture traces inferred from aerial photographs, U.S. Geol. Surv. Misc. Geol. Inv. Map 1-453, scale 1:125,000.

Condon, W. H., and J. T. Cass (1958). Map of a part of the Prince William Sound area, Alaska, showing linear geologic features as shown on aerial photographs, U.S. Geol. Surv. Misc. Geol. Inv. Map 1-273, scale $1: 125,000$.

Doser, D. I. (2006). Relocations of earthquakes (1899-1917) in south-central Alaska, Pure Appl. Geophys. 163, 1461-1476.

Doser, D. I., and W. A. Brown (2001). Study of historic earthquakes of the Prince William Sound, Alaska, region, Bull. Seismol. Soc. Am. 91, 842-857.

Doser, D. I., A. de la Peña, and A. M. Veilleux (2008). Seismicity of the Prince William Sound region and its relation to plate structure and the 1964 great Alaska earthquake, in Active Tectonics and Seismic Potential of Alaska, J. T. Freymueller, P. J. Hauessler, R. Wesson, and G. Ekstrom (Editors), American Geophysical Monograph, 179, 201-214.

Doser, D. I., N. A. Ratchkovski, P. J. Haeussler, and R. Saltus (2004). Changes in crustal seismic deformation rates associated with the 1964 Great Alaska earthquake, Bull. Seismol. Soc. Am. 94, 320-325.

Eberhart-Phillips, D., D. H. Christensen, T. M. Brocher, R. Hansen, N. A. Ruppert, P. J. Haeussler, and G. A. Abers (2006). Imaging the transition from Aleutian subduction to Yakutat collision in central Alaska, with local earthquakes and active source data, J. Geophys. Res. 111, no. B11303, 1-33.

Evans, K. R., P. R. Carlson, M. A. Hampton, M. S. Marlow, and P. W. Barnes (2000). Map of distribution of bottom sediments on the continental shelf, Gulf of Alaska, U.S. Geol. Surv. Misc. Field Studies Map: 2335, scale 1:1,000,000.

Ferguson, K. M., P. A. Armstrong, J. C. Arkle, and P. J. Haeussler (2015). Focused rock uplift above the subduction décollement at Montague 
and Hinchinbrook Islands, Prince William Sound, Alaska, Geosphere 11, no. 1, 144-159, doi: 10.1130/GES01036.1.

Freymueller, J. T., H. Woodard, S. C. Cohen, R. Cross, J. Elliott, C. F. Larsen, S. Hreinsdóttir, and C. Zweck (2008). Active deformation in Alaska, based on 15 years of GPS measurements, in Active Tectonics and Seismic Potential of Alaska, J. T. Freymueller, P. J. Haeussler, R. Wesson, and G. Ekstrom (Editors), American Geophysical Monograph $179,1-42$.

Fruehn, J., R. von Huene, and M. A. Fisher (1999). Accretion in the wake of terrane collision: The Neogene accretionary wedge off Kenai Peninsula, Alaska, Tectonics 18, 263-277.

Fuis, G. S., T. E. Moore, G. Plafker, T. M. Brocher, M. A. Fisher, W. D. Mooney, W. J. Nokleberg, R. A. Page, B. C. Beaudoin, N. I. Christensen, et al. (2008). Trans-Alaska Crustal Transect and continental evolution involving subduction underplating and synchronous foreland thrusting, Geology 36, 267-270.

Griscom, A., and P. E. Sauer (1990). Interpretation of magnetic maps of the northern Gulf of Alaska with emphasis on the source of the Magnetic Slope anomaly, U.S. Geol. Surv. Open-File Rept. 90-348, 18 pp.

Haas, J. E. (1973). Geography (Human Ecology), in The Great Alaska Earthquake of 1964, National Academy of Sciences, Washington, DC, Summary and Recommendations Volume, 89-97.

Haeussler, P. J., P. A. Armstrong, L. Liberty, K. Ferguson, S. Finn, J. Arkle, and T. Pratt (2015). Focused exhumation along megathrust splay faults in Prince William Sound, Alaska, Quaternary Sci. Rev. 113, $8-22$.

Haeussler, P. J., T. Parsons, D. P. Finlayson, P. Hart, J. D. Chaytor, H. Ryan, H. Lee, K. Labay, A. Peterson, and L. M. Liberty (2014). New imaging of submarine landslides from the 1964 earthquake near Whittier, Alaska, and a comparison to failures in other Alaskan Fjords, in Submarine Mass Movements and Their Consequences, S. Krastel, J.-H. Behrmann, D. Völker, M. Stipp, C. Berndt, R. Urgeles, J. Chaytor, K. Huhn, M. Strasser, and C. B. Harbitz (Editors), Springer International Publishing, Switzerland, Europe, 361-370.

Jaeger, J. M., and C. A. Nittrouer (2006). A quantitative examination of modern sedimentary lithofacies formation on the glacially influenced Gulf of Alaska continental shelf, Continent. Shelf Res. 26, 2178-2204.

Jaeger, J. M., C. A. Nittrouer, N. D. Scott, and J. D. Milliman (1998). Sediment accumulation along a glacially impacted coastline: North-east Gulf of Alaska, Basin Res. 10, 155-173.

Klein, L. H. (1983). Provenances, depositional rates, and heavy metal chemistry of sediments, Prince William Sound, southcentral Alaska, M.S. Thesis, University of Alaska, Fairbanks, Alaska, 96 pp.

Lagoe, M. B., C. H. Eyles, N. Eyles, and C. Hale (1993). Timing of late Cenozoic tidewater glaciation in the far North Pacific, Geol. Soc. Am. Bull. 105, no. 12, 1542-1560.

Li, J., G. A. Abers, Y. H. Kim, and D. Christensen (2013). Alaska megathrust 1: Seismicity 43 years after the great 1964 Alaska megathrust earthquake, J. Geophys. Res 118, 4861-4871.

Liberty, L. M. (2013). Near surface expression of megathrust splay faults, Prince William Sound area, Alaska, U.S. Geological Survey Earthquake Hazards Program Final Report for Award \#G11AP20143, 23 pp., http:// earthquake.usgs.gov/research/external/reports/G11AP20143.pdf (last accessed August 2014).

Liberty, L. M., S. P. Finn, P. J. Haeussler, T. L. Pratt, and A. Peterson (2013). Megathrust splay faults at the focus of the Prince William Sound asperity, Alaska, J. Geophys. Res. 118, doi: 10.1002/jgrb.50372.

Malloy, R. J. (1964). Crustal uplift southwest of Montague Island, Alaska, Science 146, 1048-1049, doi: 10.1126/science.146.3647.1048.

McCalpin, J. P., and G. A. Carver (2009). Paleoseismology of compressional tectonic environments, Int. Geophys. 95, 315-421.

Moffit, F. H. (1954). Geology of the Prince William Sound region, Alaska, in Mineral resources of Alaska, 1951-53, U.S. Geol. Surv. Bull. 989-E, E225-E310.
Molnia, B. F. (1977). Surface sedimentary units of the Gulf of Alaska Continental shelf: Montague island to Yakutat Bay, U.S. Geol. Surv. Open-File Rept. 77-30.

Page, D. S., P. D. Boehm, G. S. Douglas, and E. A. Bence (1995). Identification of hydrocarbon sources in the benthic sediments of Prince William Sound and the Gulf of Alaska following the Exxon Valdez oil spill, ASTM Spec. Techn. Publ. 1219, 41-83.

Peltier, W. R., and R. G. Fairbanks (2006). Global glacial ice volume and last glacial maximum duration from an extended Barbados sea level record, Quaternary Sci. Rev. 25, 3322-3337.

Plafker, G. (1969). Tectonics of the March 27, 1964 Alaska earthquake, U.S. Geol. Surv. Profess. Pap. 543-1, 1-74.

Shennan, I., R. Bruhn, N. Barlow, K. Good, and E. Hocking (2014). Late Holocene great earthquakes in the eastern part of the Aleutian megathrust, Quaternary Sci. Rev. 84, 86-97.

Taliaferro, N. L. (1932). Geology of the Yakataga, Katalla, and Nichawak districts, Alaska, Bull. Geol. Soc. Am. 43, 749-782.

von Huene, R., R. J. Malloy, G. G. Shor Jr., and P. Saint-Amand (1967). Geologic structures in the aftershock region of the 1964 Alaskan earthquake, J. Geophys. Res. 72, 259-268.

Wells, D. L., and K. J. Coppersmith (1994). New empirical relationships among magnitude, rupture length, rupture width, rupture area, and surface displacement, Bull. Seismol. Soc. Am. 84, 974-1002.

Wiles, G. C., D. J. Barclay, P. E. Calkin, and T. V. Lowell (2008). Century to millennial-scale temperature variations for the last two thousand years indicated from glacial geologic records of Southern Alaska, Global Planet. Change 60, 115-125.

Wilson, F. H., and C. P. Hults (2012). Geology of the Prince William Sound and Kenai Peninsula region, Alaska, U.S. Geol. Surv. Sci. Invest. Map: 3110, 37 pp., 1 sheet, scale 1:350,000.

Yilmaz, O. (2001). Seismic Data Analysis: Processing, Inversion, and Interpretation of Seismic Data, Vol. II, Investigations in Geophysics 10, Society of Exploration Geophysicists, Tulsa, Oklahoma, doi: 10.1190/ 1.9781560801580.

Zander, P. D., D. S. Kaufman, S. C. Kuehn, K. L. Wallace, and R. S. Anderson (2013). Early and late Holocene glacial fluctuations and tephrostratigraphy, Cabin Lake, Alaska, J. Quaternary. Sci. 28, 761-771.

Zweck, C., J. T. Freymueller, and S. C. Cohen (2002). Three-dimensional elastic dislocation modeling of the postseismic response to the 1964 Alaska earthquake, J. Geophys. Res. 107, ECV-1.

Boise State University

Department of Geosciences

1910 University Drive

Boise, Idaho 83725

lliberty@boisestate.edu

(S.P.F., L.M.L.)

U.S. Geological Survey

4200 University Drive

Anchorage, Alaska 99508

(P.J.H.)

U.S. Geological Survey

12201 Sunrise Valley Drive

Mail Stop 905

Reston, Virginia 20192

(T.L.P.)

Manuscript received 11 September 2014; Published Online 15 September 2015 